\title{
Freezing-thawing tests on natural pyroclastic samples
}

\author{
R.R. Peláez, F. Casini, E. Romero \& A. Gens \\ ETCG, Universitat Politècnica de Catalunya, Barcelona, Spain \\ G.M.B. Viggiani \\ DICII, Università di Roma Tor Vergata, Roma, Italy
}

\begin{abstract}
Artificial Ground Freezing is one of the construction techniques that were extensively adopted during construction of Line 1 of Napoli Underground, to ensure stability and waterproofing of the platform tunnels and inclined passageways during excavation below the ground water table through loose granular soils of pyroclastic origin (Pozzolana) and a fractured soft rock (Neapolitan Yellow Tuff). The aim of the paper is to study the behavior of the Pozzolana and Neapolitan Yellow Tuff subject to freezing and thawing cycle at constant vertical stress under oedometric condition. As the temperature decreases the ice content increases and a liquid ice-surface tension, $\sigma_{\mathrm{li}}$, develops at the interface of the two phases as the temperature decreases. This tension must be balanced by the suction $s$ defined as the difference in frozen and liquid water pressure $P_{\mathrm{i}}$ and $P_{1}$ respectively. Two oedometers working under suction and temperature controlled conditions have been modified to work with temperature below zero degree. The stress path followed by samples reproduce the in situ vertical stress interested by freezing and thawing.
\end{abstract}

\section{INTRODUCTION}

Artificial Ground Freezing (AGF) may be used to provide ground support, groundwater control, or structural underpinning during construction. The frozen earth wall, which is constructed prior to excavation, for practical purposes eliminates the need for sheeting of the earth, site dewatering, soil stabilization, or concern for movement of adjacent ground. AGF has been extensively used during construction of Line 1 of Napoli Underground, to ensure stability and waterproofing of the platform tunnels and inclined passageways during excavation below the ground water table through loose granular soils of pyroclastic origin (Pozzolana) and a fractured soft rock (Neapolitan Yellow Tuff).

It is a versatile technique that involves the use of refrigeration to convert in situ soil pore water into ice. The ice becomes a bonding agent, fusing together adjacent particles of soil or blocks of rock to increase their combined strength and make them impervious to water seepage. The ice content increases decreasing temperature, two phases of water liquid and solid occupy the pore space. A liquid ice-surface tension, $\sigma_{\mathrm{li}}$, develops at the interface of the two phases. This tension must be balanced by the suction $s$ defined as the difference in frozen and liquid water pressure $P_{\mathrm{i}}$ and $P_{1}$ respectively.

Under the hypothesis of equal chemical potential the ice pressure should be derived by the Clausius
Clayperon equation (see Nishimura et al 2009, Gens 2010, Casini et al 2013) as function of pore water pressure and temperature.

The freezing retention model which links the degree of saturation of liquid water to the suction $\mathrm{s}=\mathrm{Pi}$ $\mathrm{Pl}$ can be derived using the Van Genuchten (1980) model with the ice entry value $\left(s_{\mathrm{i}}\right)$ related to the air entry value in unsaturated condition $\left(s_{a}\right)$ through the relations $s_{\mathrm{i}}=s_{\mathrm{a}} \sigma_{\text {li }} / \sigma_{\text {la }}$ where $\sigma_{\text {la }}$ and $\sigma_{\text {li }}$ are the liquidair and liquid-ice surface tensions.

The modification of pore frozen and liquid water pressure regimes modify the effective stress acting on soil skeleton, which, in turn, induces mechanical deformation.

Volume change of thawing soil will result from both phase change (ice to water) and flow of excess water out of the soil. Drainage of the thawed soil leads to additional volume change, the amount depending on consolidation and soil structural changes that occurred during the previous freezing cycle.

A variety of factors such as stress acting, thermal cycle, moisture change histories, influence the amount and distribution of ice in frozen ground. For ice-rich soils, a rough estimate of the amount of thaw settlement can be based on the visible thickness of ice lenses. This method can result in significant errors; duplicating field conditions (Andersland and Ladanyi 2004). 
In this work the behavior of Pozzolana and Yellow Tuff has been investigated using two oedometers apparatuses working under temperature and suction controlled modified for temperature below zero degrees. On freezing, the ice content increases, the suction as well and the frozen soil swell due to the decreases of effective stress acting on soil skeleton and to the phase change of water. On thawing, the ice content and the suction decreases with increasing temperature, and for existing overburden pressures the soil skeleton must adapt itself to a new equilibrium in terms of effective stress and void ratio due also to the degradation induced by cycle of freezing and thawing.

Russo et al (2012) reported the evolution of settlement of a reference point during construction of Line 1 in Naples (Figure 1). A light swelling is measured during swelling (points 2-3) while a more pronounced shrinkage is measured during freezing (points 5-6). It should be highlighted that thawing in this case happen after the excavation of platform tunnel and permanent lining installation which in turn contributed also to the measure shrinkage. The understanding of the physics phenomena at the base of thaw settlement are of fundamental importance in the application of AGF as ground-support systems in urban tunneling where the differential settlement should damage the building adjacent.

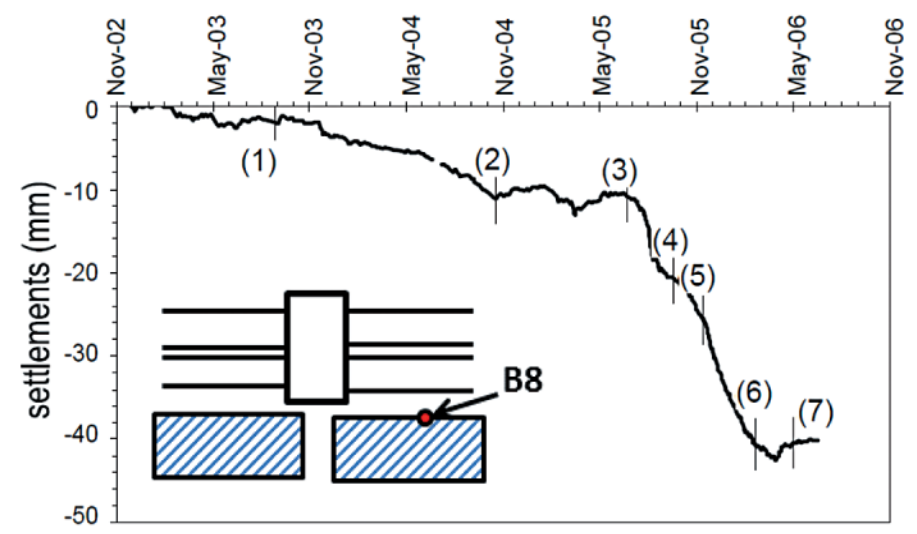

Figure 1. Settlements of reference point B8. (1) to (2): installation of anchors; (2) to (3): ground freezing; (4): excavation of platform tunnel; (5): permanent lining installation; (5) to (6): thawing; (7): underpinning. (Russo et al., 2012).

A brief description of the modification made on the apparatuses and the first experimental results obtained at different vertical stress are presented and discussed. The results shows the importance of the vertical stress applied to the deformation accumulated after a cycle of freezing and thawing in particular as the vertical stress increases the irreversible deformation decreases. The deformation accumulated for the same vertical stress tested are greater in Pozzolana than in Yellow Tuff.

\section{EXPERIMENTAL PROGRAM}

\subsection{Equipment}

The Figure 2 shows the configuration of the experimental set-up of the experimental apparatuses used during in this investigation. The experimental set-up is composed by a thermal bath in which the refrigerating fluid circulate at controlled temperature ranging between $+30^{\circ} \mathrm{C}$ and $-30^{\circ} \mathrm{C}$.

The temperature is controlled with a thermostat in the thermal bath. The refrigerating medium is a mixed fluid composed by 50-50 proportions of water and ethylene glycol.

Two oedometer cells (see Romero (1999)) have been modified to be used with temperature below zero degree, equipped with thermocouples to monitor the temperature in the sample and in the thermal bath and immersed in the thermal bath (Peláez, 2013).

The water drainage is allowed through the bottom and connected to reservoir (for details see Peláez 2013). The vertical stress is applied through compressed air at the top of the sample regulated by step. The air used to apply vertical stress on the top of sample has been dessicated through a salt mixture (4 in Figure 2) located in a chamber.

A data acquisition system has been developed to read signals in millivolts from thermocouples and LVDTs onto the oedometer cells, and for last a data processing system that use a software that convert those signals to temperatures $\left({ }^{\circ} \mathrm{C}\right)$ and displacements (mm).

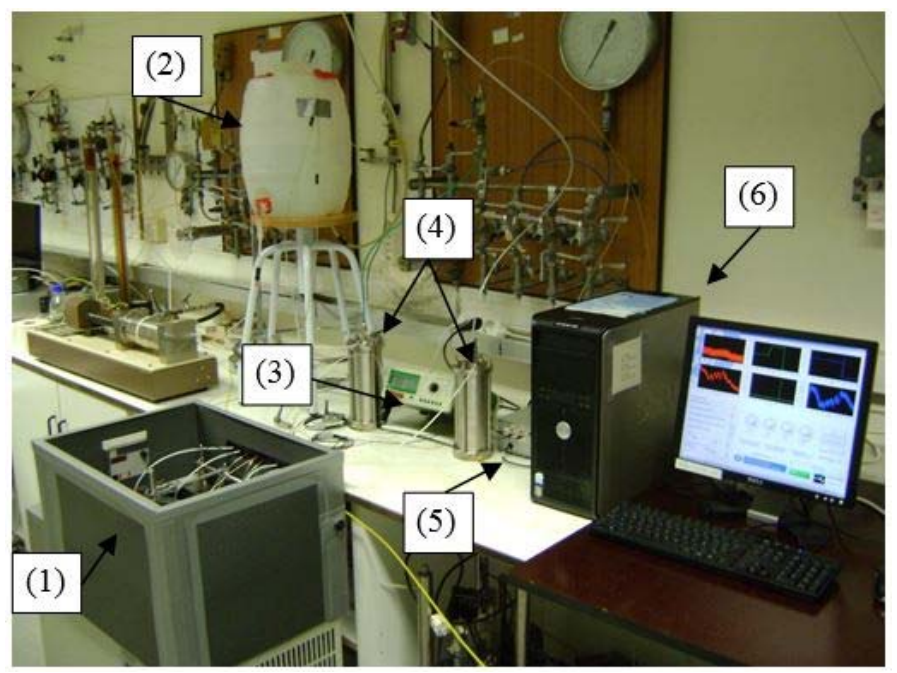

Figure 2. Experimental set-up. (1) Thermal bath with oedometers cells, (2) water reservoir, (3) external thermocouple, (4) air desiccation chamber, (5) data acquisition system, (6) data processing unit.

\subsection{Materials}

The samples of Pozzolana and Yellow Tuff used in this investigation have been retrieved in the subsoil of the Municipio Station, extension of Line 1 Naples 
underground (see Viggiani \& De Sanctis 2009, Russo et al 2012). The samples were retrieved as a part of the drilling campaign during the construction of tunnels performed by Tecno-in SpA.

Two undisturbed core samples has been used at UPC Geotechnical Laboratory. The samples of natural Pozzolana has been retrieved in 10-12m, while the Yellow Tuff in 20-24 m depths. The basic properties of these materials have been obtained and summarized in Table 1 . The particle size distributions by sieve analysis (ASTM D22-63) of Pozzolana and Yellow Tuff are reported in Figure 3.

The percentage with $\mathrm{d}>2 \mathrm{~mm}$ is $50 \%$ for both materials, the sand percentage is $40 \%$ for Yellow Tuff and 50\% for Pozzolana.

Table 1. Initial (natural) conditions of materials.

\begin{tabular}{lcc}
\hline Properties & Pozzolana & Yellow tuff \\
\hline Density, $\mathrm{Mg} / \mathrm{m}^{3}$ & 1.67 & 1.15 \\
Dry density, $\mathrm{Mg} / \mathrm{m}^{3}$ & 1.33 & 1.03 \\
Specific gravity, $\mathrm{Mg} / \mathrm{m}^{3}$ & 2.46 & 2.46 \\
Void ratio & 0.84 & 1.38 \\
Porosity & 0.46 & 0.58 \\
Water content, \% & 24.46 & 11.17 \\
Degree of saturation,\% & 70.64 & 19.90 \\
\hline
\end{tabular}

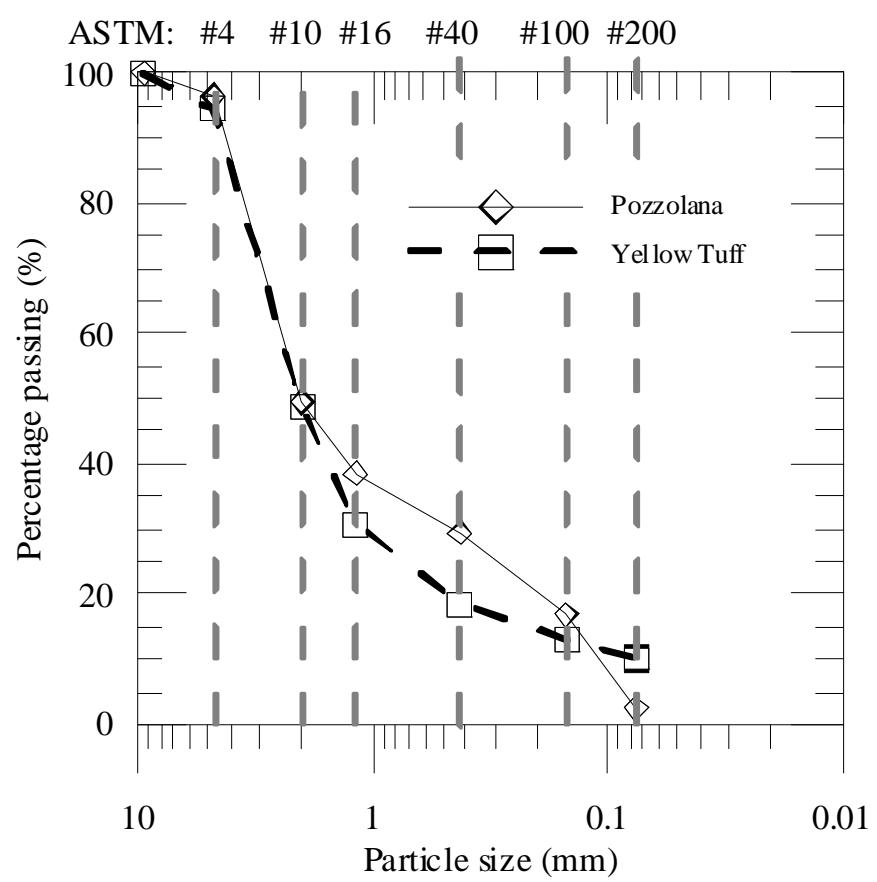

Figure 3. Particle size distribution.

\subsection{Tests programme}

The sample has been trimmed and placed into the cell ring (50 mm in diameter and $20 \mathrm{~mm}$ high). The stress path followed for each sample is reported in
Figure 4. It is divided in five steps defined as follows:

- Saturation stage with a back pressure $p_{\mathrm{w}}=10$ $\mathrm{kPa}$ at the bottom of the sample. This phase last mostly 6 hours. During this stage the upper valve was at atmospheric condition. Water outlet has been observed at the top boundary ensuring water saturated conditions;

- Compression phase up to the target vertical stress by step. Each step lasting 24 hours. The maximum total vertical stress tested were $200-500 \mathrm{kPa}$ for Pozzolana, 500-800 $\mathrm{kPa}$ for Yellow Tuff. The target vertical stress has been chosen as representative of the in situ vertical stress typically acting on Pozzolana and Yellow Tuff;

- Temperature cycle: freezing and thawing. The temperature cycle $+22^{\circ} \mathrm{C}$ to $-20^{\circ} \mathrm{C}$ has been applied by step at constant vertical stress. Each step lasting 6 hours. The samples have being maintained at the minimum temperature of $-20^{\circ} \mathrm{C}$ for 48 hours. The displacement has been monitored during this period to check the creep behavior of the frozen samples. After that the sample has been thawed by step up the initial temperature;

- Unloading phase at temperature of $22^{\circ} \mathrm{C}$ by step to zero vertical stress, sample desmantling (see Figure 4).

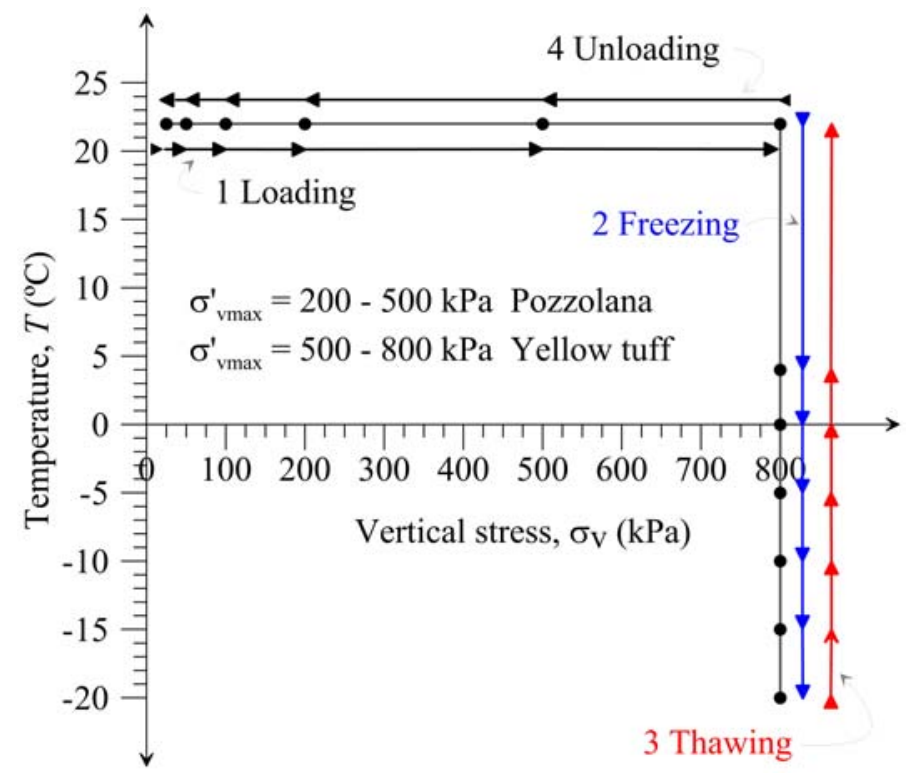

Figure 4. Stress and Temperature paths followed on two samples of Pozzolana and two samples Yellow tuff.

The thermal bath has been isolated by the laboratory environment through a cap to avoid temperature fluctuations. The top cap of the oedometer has been modified with a proper hard plastic cap because during the freezing process the metallic connection freezes. Such kind of frozen brine around the connection to the LVDT point measurement affects the 
measurement of the vertical displacement. To avoid this phenomena the top cap has been changed to plastic ones. Two thermocouple has been inserted in the apparatuses just in contact with samples to check the temperature acting on the soil.

\section{EXPERIMENTAL RESULTS}

The experimental results of four odemeter tests are presented in this section: two oedometer tests for Pozzolana with $\sigma_{\text {vmax }}=200$ and $500 \mathrm{kPa}$ and two oedometers tests for Yellow Tuff with $\sigma_{\text {vmax }}=500$ and $800 \mathrm{kPa}$.

The experimental results for Pozzolana are reported in Figure 5 a-b. The void ratio decreases up to $200 \mathrm{kPa}$ is similar in both samples with a $\Delta \mathrm{e} \sim 0.02$. The samples compressed up to $500 \mathrm{kPa}$ shows a yielding in the last steps. The preconsolidation stress should be between 200 and $500 \mathrm{kPa}$. The freezing-thawing cycle shows an accumulated plastic deformation $\Delta \mathrm{e}(T)=0.03$ for sample with $\sigma_{\mathrm{vmax}}=200 \mathrm{kPa}$ and $\Delta \mathrm{e}(T)=0.02$ for sample with $\sigma_{\mathrm{vmax}}=500 \mathrm{kPa}$.

In the unloading step, the point follows a line in the e-logsv plane with an inclination $C_{\mathrm{s}}=0.001$ for $\sigma_{\text {vmax }}=200 \mathrm{kPa}$ (Figure 5a) and $C_{\mathrm{s}}=0.004$ for $\sigma_{\mathrm{vmax}}=500 \mathrm{kPa}$ (Figure 5b).

The results of Yellow Tuff are reported in Figure 6(a) and (b). During the compression stage both samples shows a similar behavior up to $500 \mathrm{kPa}$. The last step for sample up to $800 \mathrm{kPa}$ shows a light increases of the slope in the $e-\log \sigma \mathrm{v}$ not a proper yielding. This results suggest that the preconsolidation stress for Yellow Tuff is reached for higher vertical stresses.

The freezing-thawing cycle exhibit an irreversible void ratio $\Delta \mathrm{e}$ depending, also in this case, from the vertical stress acting. The $\Delta \mathrm{e}(\mathrm{T})=0.012$ with $\sigma_{\mathrm{vmax}}=500 \mathrm{kPa}$ and $\Delta \mathrm{e}(\mathrm{T})=0.009$ with $\sigma_{\mathrm{vmax}}=800$ $\mathrm{kPa}$.

The inclination of the unloading line $\mathrm{Cs}=0.0017$ with $\sigma_{\mathrm{vmax}}=500 \mathrm{kPa}$ (Figure 6a) and $C_{\mathrm{s}}=0.0012$ for $\sigma_{\mathrm{vmax}}=800 \mathrm{kPa}$ (Figure 6b).

The volume change after cycle of freezing and thawing is the result of phase change (ice to water) and flow of volume change of thawing soil will result from both phase change (ice to water) and flow of excess water out of the soil. Drainage of the thawed soil leads to additional volume change, the amount depending on consolidation and soil structural changes that occurred during the previous freezing cycle.

A variety of factors such as stress acting, thermal cycle, moisture change histories, influence the amount and distribution of ice in frozen ground. For ice-rich soils, a rough estimate of the amount of
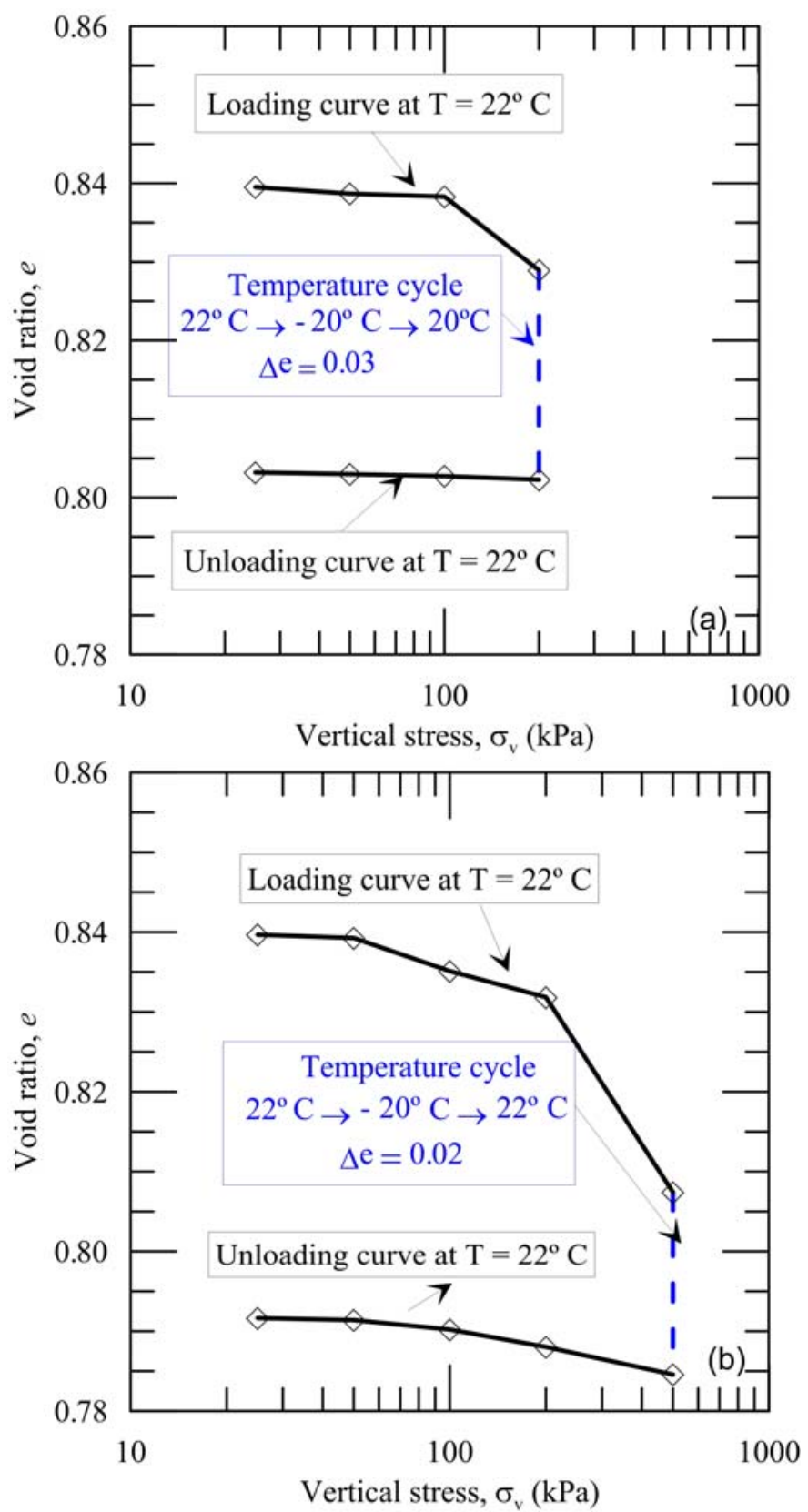

Figure 5. Oedometer tests on Pozzolana in the $\log \sigma_{\mathrm{v}}-e$ plane: (a) $\sigma_{\mathrm{vmax}}=200 \mathrm{kPa}$; (b) $\sigma_{\mathrm{vmax}}=500 \mathrm{kPa}$

thaw settlement can be based on the visible thickness of ice lenses. This method can result in significant errors; duplicating field conditions (Andersland and Ladanyi 2004).

The deformation accumulated after a cycle of freezing $\left(-20^{\circ} \mathrm{C}\right)$ and thawing $\left(+20^{\circ} \mathrm{C}\right)$ are reported in terms of change in void ratio $\Delta \mathrm{e}(\mathrm{T})$ as a function of $\sigma_{v \max }$ in Figure 7 for Pozzolana and Yellow Tuff.

The accumulated void ratio after a cycle of freezing and thawing decreases as the vertical stress increases for both Pozzolana and Yellow Tuff. The accumulated void ratio is higher in Pozzolana than in Yellow Tuff. 

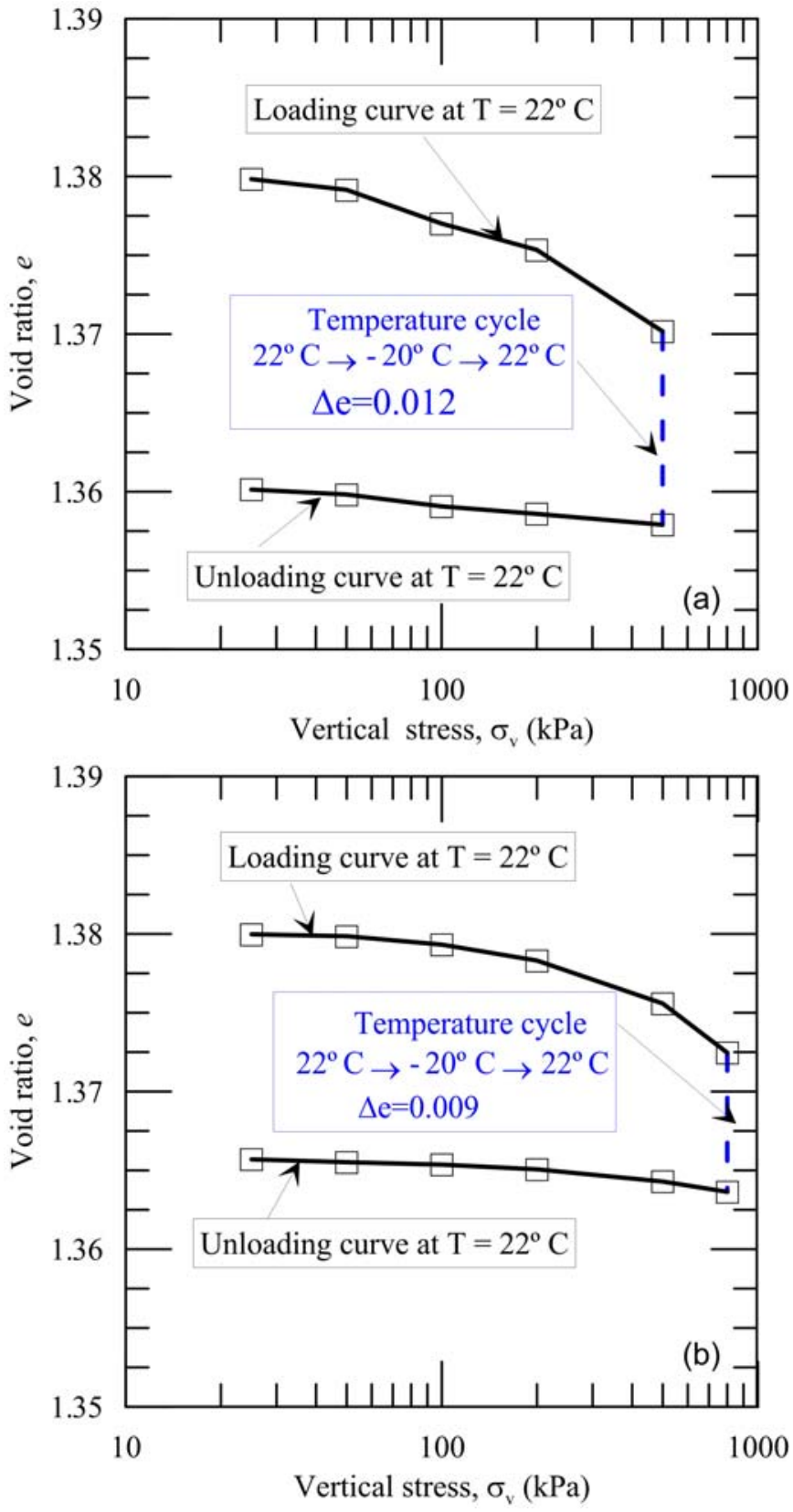

Figure 6. Oedometer tests on Yellow Tuff in the $\log _{\mathrm{v}_{\mathrm{v}}}-e$ plane: (a) $\sigma_{\mathrm{vmax}}=500 \mathrm{kPa}$; (b) $\sigma_{\mathrm{vmax}}=800 \mathrm{kPa}$

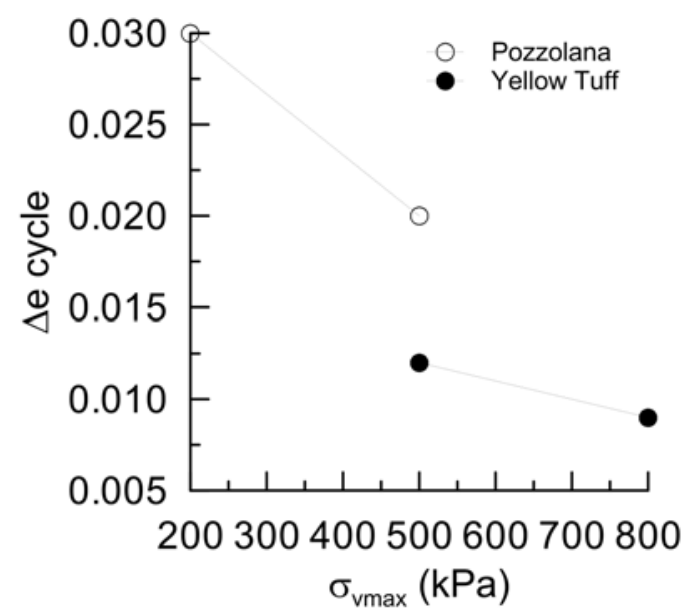

Figure 7. Void ratio extent accumulated after freezing and thawing as function of the $\sigma_{\mathrm{vmax}}$

\section{CONCLUSIONS}

In this work have been presented the first experimental results on two pyroclastic soils subject to compression and temperature cycle below zero degree. A temperature controlled apparatuses working under suction controlled condition has been modified to work with temperature below zero. The oedometer has been equipped with thermo couple to measure the temperature in the sample. The top cap of the apparatus has been modified to avoid the freezing of the connection with the LVDT to measure the vertical displacement.

The experimental set-up is composed by a thermal bath in which the refrigerating fluid circulate at controlled temperature. The refrigerating medium is a mixed fluid composed by 50-50 proportions of water and ethylene glycol.

The samples tested were two pyroclastic soils retrieved from Naples, where artificial ground freezing has been extensively used during construction of Line 1 Underground. The AGF has been used to ensure stability and waterproofing of the platform tunnels and inclined passageways during excavation below the ground water table through loose granular soils of pyroclastic origin (Pozzolana) and a fractured soft rock (Neapolitan Yellow Tuff).

Four samples of Pozzolana and Yellow Tuff has been tested under constant vertical stress with temperature cycle ranging between laboratory temperature to $-20^{\circ} \mathrm{C}$ by step.

The target vertical stress has been chosen as representative of the in situ vertical stress typically acting on Pozzolana and Yellow Tuff. One common vertical stress has been tested also to compare the behavior of the two pyroclastic soils subject to the same stress path in term of vertical stress and temperature.

This first results shows that the accumulated void ratio change after a cycle of freezing and thawing increases with decreasing vertical stress for Pozzolana and Yellow Tuff as well.

For the same vertical stress the void ratio exhibit by Pozzolana is mostly double compared to the Yellow Tuff.

Further investigation must be done at different vertical stress and temperature. The calibration of the apparatuses must be completed.

\section{ACKNOWLEDGMENTS}

The first author wish to extend his gratitude to the Ministerio de Educación Superior, Ciencia y Tencnología (MESCyT) of Dominican Republic for providing financial support for the Master's degree studies in Geotechnical engineering at UPC.

The financial support of the European Commission for the second author through the " Marie Curie 
Intra European Fellowship” (EU FP7-NuMAGF, grant agreement 272073) is acknowledged. The authors are grateful to Tecno-in SpA for their technical support to provide the samples retrieved in Napoli.

\section{REFERENCES}

Andersland, O.B. \& Ladanyi, B. (2004). Frozen ground engineering. Wiley and Sons Inc., New Jersey.

Casini, F., Gens, A., Olivella, S., Viggiani, G.M.B. 2013. Coupled phenomena induced by freezing in a granular material. In: Coupled Phenomena in Environmental Geotechnics: From Theoretical and Experimental Research to Practical Applications - Proceedings of the International Symposium, ISSMGE TC 215, pp. 467-473

Gens, A. 2010. Soil-enviroment interactions in geotechnical engineering. Géotechnique 60(1): 3-74.

Nishimura, S., Gens, A., Olivella, S. \& Jardine, R.J. (2009). THM-coupled finite element analysis of frozen soil: formulation and application. Géotechnique 59(3): 159-171.

Peláez, R.R. 2013. Congelación artificial de dos suelos naturales. Un enfoque experimental con desarrollo de equipo, Master thesis Universitat Politècnica de Catalunya: 1-76

Russo, G., Viggiani, C. \& Viggiani, G.M.B. 2012. Geotechnical design and construction issues for lines 1 and 6 of the Naples underground. Geomechanik und Tunnelbau 5(3): 300-311.

Viggiani, G.M.B. \& de Sanctis, L. 2009. Geotechnical aspects of underground railway construction in the urban environment: The examples of Rome and Naples. Geological Society Engineering Geology Special Publication 22(1): $215-240$ 